\title{
Calculation Analysis of Batako Press Production Cost in CV. Batako Anugerah Baubau, Indonesia
}

\author{
Endang Tri Pratiwi ${ }^{1 *}$, La Ode Dedi Abdullah ${ }^{1}$, Rudi Abdullah ${ }^{1}$, Asrianti Dja’wa²
}

\author{
${ }^{1}$ Universitas Muhamadiyah Buton, Baubau, Indonesia \\ ${ }^{2}$ Universitas Halu Oleo, Kendari, Indonesia \\ *Corresponding author.Email: endangtripratiwi12@gmail.com
}

\begin{abstract}
The purpose of this study was to determine whether the production cost of press brick in CV. Batako Anugerah Baubau was right. The population in this study is the calculation of the products basic cost of Press Brick Products in CV. Batako Anugerah Baubau. The sample in this study is the calculation of the products basic cost of press brick on CV. Batako Anugerah Baubau at 2014. Data collection by conducting observations, interview and documentation. The research method used is a quantitative method. The results showed that calculation of production costs have done according to calculations in CV. Batako Anugerah Baubau was easier than calculations according to the theory of process costs. Production costs based on the calculation process cost method amount Rp173,475,000,- or Rp1,388,- per unit, while according to company calculations, production costs are Rp169,790,000,- or Rp1,359,- per unit, resulting in a difference in production costs of Rp3,685 million or Rp29,- per unit. The implications of this research were expected to be able to contribute ideas for the leadership of the company concerned to take decisions in calculating the production costs of the block and as information source and also thought contribution for all those who need it.
\end{abstract}

Keywords: calculation analysis, Batako Press, production cost

\section{INTRODUCTION}

Entering the free market, competition in the business world is becoming tighter. The development of the business world in Indonesia today is very rapid and causes very tight competition between companies, with this condition the company must try to keep abreast of developments in order to maintain the survival of the company and obtain maximum profits [1]. In essence, every company is established with the aim of prospering its owners, both industrial, trade and service companies. Therefore, it aims to obtain the maximum possible profit with certain expenses so that customer satisfaction and company survival are met [2]. To be able to achieve these objectives the company must carry out activities namely production spending, marketing, personnel, and activities administrative activities that are related to one another.

One of the most important activities that needs attention from industrial companies is production activities, because that activity will be carried out a process to process raw materials into finished goods or semi-finished goods into finished goods [3]. Producing a product must pay attention to how much the cost of production is produced, because the cost of production is one of the most important elements of the selling price, so that later the selling price of the finished goods depends on the size of the cost of the product. Errors in determining the total cost of goods as well as per unit will bring an unfavorable effect on the continuity of the business, therefore determining the cost of goods is a very important problem in a company [4]. The cost of production is high too, so that with competition both the price and quality of an item will be difficult to market and vice versa if the selling price is low to below the cost of production will cause a loss to a company.

$\mathrm{CV}$. Batako Anugerah Baubau is an individual company that produces several types of building material products including bricks, paving blocks, and others. of the cost of goods carried out by rounding all elements of the cost of production, while the cost of production per unit is determined by the total cost of production with the volume of production needed or expected to be produced. This method must be used when dealing with accounting principles, affecting both the total cost of the product and the way it is presented in the income statement [5].

Brick is a component of building materials made from a mixture of cement, sand and water that can be printed with a printing press so that it cannot be destroyed again when immersed in water. Batako as a component of building materials in the building sector at this time is needed because of the rapid growth rate of development in the building sector. Brick can be used as a substitute for bricks and padas. Nowadays brick making is increasingly known and widely used by the wider community for example as building material [6].

The prospect of the brick making company today can be said to have a pretty bright future. With the existence of a brick-and-mortar company, it will be able to tackle environmental problems, because it is not through excavation of land such as in the excavation of rock and the red stone industry [7]. In brick making companies in determining the cost of production is based on the imposition of raw material costs, labor costs, and indirect 
production costs with the actual costs incurred on the brick making products produced. Press brick making company is one of the brick making companies that has complete equipment [8]. This company in its business activities to buy cement, sand, and then processed through several processes can then be sold. The purpose of this study was to determine whether the production cost of press brick in CV. Batako Anugerah Baubau was right.

\section{METHOD}

\subsection{Population And Sample}

Population is a group of people, events or everything that has certain characteristics [9]. The population in this study is the calculation of the cost of basic products Press Brick Products in CV. Batako Anugerah Baubau. The sample in this study was the calculation of the cost of the Press Brick Products on the CV. Batako Anugerah Baubau in 2014.

\subsection{Data Collection Technique}

Data analysis techniques used are as follows:

a. Calculate the actual cost of goods according to the company and that should be based on the theory of the process of cost of goods.

Cost of production $=$ raw material costs + labor costs + factory overhead costs

b. Calculate the cost of goods per unit. The method of cost of goods per unit is a method of collecting cost of products in which costs are collected for each unit of time.

c. Calculating the difference between the actual cost of production according to the company and that should be based on the theory of the cost of processing method.

\subsection{Data Analysis Method}

Quantitative method is a research method based on the philosophy of positivism used to examine a particular population or sample, sampling techniques are generally carried out randomly, data collection using a quantitative data analysis research instrument with the aim of testing the hypotheses that have been set [10].

\section{RESULTS AND DISCUSSION}

\subsection{Calculation of Cost of Production According to Cost of Process}

In determining the cost of goods based on the theory of cost of goods the process will be different from the calculation of the cost of production according to the calculation of the cost of production according to the calculation of the company [12]. This can occur due to the calculation of companies that have not calculated or included the elements of auxiliary materials (water), direct labor costs (incentive) and the cost of depreciating some components of factory overhead costs into the calculation of the cost of production so that there will be differences in calculations between those based on company calculations with calculations based on the theory of the cost of the process [11].

Calculation of cost of production of brick making $\mathrm{CV}$. Batako Anugerah Baubau is based on the theoretical calculation of the cost of the process is as follows:
1. Initial production
$=0$ units
2. Production undertaken
3. Unit in process
$=124.952$ units
$=8.512$ units
Amount $=116.440$ units

Production costs can be grouped into 3 (three) parts, namely:

1. Raw material costs

$$
\begin{array}{ll}
\text { - Cement } 310 \text { pack@ IDR 54,000 } & =\text { IDR } 16.740 .000 \\
\text { - Sand 312 } \mathrm{m}^{3} @ \text { IDR 400,000 } & =\text { IDR124.800.000 } \\
\text { - 3.500 liters water@ IDR 1,000 } & =\text { IDR 3.500,000 } \\
\text { Total raw material costs } & =\text { IDR145.040.000 }
\end{array}
$$

2. Direct labor costs

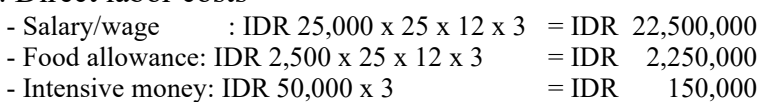

Total TK Direct fee

$=$ IDR 24.900 .000

3. Factory overhead costs

Depreciation of fixed assets and means of production

a. The factory building is worth IDR $25,000,000$ IDR $1,000,000$ economic elements 10 years straight line depreciation so that the annual depreciation of IDR $2,500,000$ is charged at $40 \%$

b. Mixing machine IDR 800,000 economic life of 5 years straight-line depreciation, annual depreciation

c. Generator set IDR 200,000 economic life of 5 years, straight-line depreciation so that the annual depreciation

d. 1 piece of iron padlock IDR 250,000 economic life of 5 years depreciation per year

e. The dynamo molding machine is worth IDR $8,000,000$ economic life of 10 years straight line depreciation so that the annual depreciation

f. Thomas diesel engine is worth IDR 350,000. economic age of 10 years shrinking per year

g. Solar fuel IDR $50,000 \times 12$

h. Electricity IDR 5,000 per month

i. Lubricating oil IDR 26,000 per month

j. The cost of maintaining and repairing assets and production equipment is IDR 45,000 is charged $40 \%$

IDR 80,000

IDR $\quad 40,000$

IDR $\quad 50,000$

IDR 800,000

IDR $\quad 35,000$

IDR 600,000

IDR 600,000

IDR 312,000

IDR $\quad 18,000$

IDR $3,535,000$

Total production costs IDR $173,475,000$

So the cost of production per unit in the printing department is: $\operatorname{IDR} 173,475,000 / 124,952=\operatorname{IDR} 1,388$

Table 1 Calculation of press brick production costs according to the cost of process in CV. Batako Anugerah Baubau 2014

\begin{tabular}{|llc|}
\hline \multirow{1}{*}{ Products } & \multicolumn{2}{c|}{ Production Cost } \\
\cline { 2 - 3 } Batako Press & Each unit & Total $(\mathrm{x} \mathrm{124.952)}$ \\
Amount & IDR 1,388 & IDR $173,475,000$ \\
& IDR 1,388 & IDR $173,475,000$ \\
\hline
\end{tabular}


Based on the table above, it is illustrated that the cost of production of a brick press is successively mentioned per section so that the total production cost is IDR 173,475,000 while per unit of IDR 1,388. Calculation of the cost of production per unit of each brick press product according to CV. Batako Grace.

$$
\text { Batako Press }=\frac{\text { IDR } .173 .475 .000}{124.952 \text { unit }}=\text { IDR 1,388 }
$$

Determination of the cost of production per unit of each brick press product above is obtained from: production costs for brick press is IDR $173,475,000$ divided by the number of brick press products produced in 2014 as many as 124,952 units so that the cost of production per unit is IDR 1,388. From the calculation of the cost of production of the brick press above, a report on the cost of production can be prepared according to the theory of the process cost as follows:

1. Raw material costs

- Semen310 sak@ IDR 54,000

- Sand 312 m3@ IDR 400,000

-3,500 liters water@ IDR 1,000

$=$ IDR $16,740,000$

$=$ IDR $124,800,000$

$=$ IDR $3,500,000$

Amount

2. Direct labor costs

- Salary / wages for 3 people

- Food allowance for 3 people

- Money intensive for 3 people

$=$ IDR $145,040,000$

$=$ IDR $22,500,000$

$=$ IDR $2,250,000$

$=$ IDR 150,000

Amount

$=$ IDR 24,900,000

Depreciation of fixed assets and production equipment $=$ IDR 2,005,000; Diesel fuel IDR 50,000 × $12=$ IDR 600,000; Electricity IDR 50,000 per month = IDR 600,000; Lubricating oil IDR 26,000 per month = IDR 312,000; Cost of maintaining/repairing production equipment $=$ IDR 18,000; Amount $=$ IDR 3,535,000. So, basic Production Price of Batako Press $=$ IDR 173,475,000

\subsection{Principal Price Analysis of Batako Press Production at CV Batako Anugerah}

Based on the results of the calculation of total cost of goods as well as cost of goods per unit, both calculated according

to the company and calculated according to the theory of the process cost of goods in each section, it turns out that the calculation of the cost of production is calculated according to the theory of meetode cost of the theory is greater than the calculation which is carried out according to company calculations. For more details calculation of the difference between the cost of goods manufactured calculated according to company calculations with calculations according to the theory of cost of processing methods can be seen as follows:

Table 2 Calculation of cost difference in press brick production according to the company calculation by calculation the principal price method for process on $\mathrm{CV}$ batako anugerah Baubau

\begin{tabular}{|llc|}
\hline \multicolumn{1}{|c}{ According to } & \multicolumn{2}{c|}{ Cost of goods sold } \\
\cline { 2 - 3 } CV. Batako & Each unit & Total \\
\cline { 2 - 3 } $\begin{array}{l}\text { Anugerah } \\
\text { Cost of Process }\end{array}$ & IDR 1,359 & IDR 169,790,000 \\
\hline
\end{tabular}

From table above, it can be seen that the basic price according to the company is IDR $169,790,000$ or IDR 1,359 per unit, while the total cost of production according to the theoretical calculation of the cost of processing method is IDR $173,475,000$ or IDR 1,388 per unit. So the difference of IDR 3,685,000 or IDR 29 per unit. In this case that the profit to be obtained according to the calculation of the company is greater and means that the company experiences false profits or profits that are not real. Furthermore, to find out the causes of the difference in the cost of production, then further differences in the elements compared to the cost of production itself are raw materials, auxiliary costs, direct labor costs and factory overhead costs[12].

With the comparison of the elements of the cost of production, it will be known the cause of the calculation of the cost of production according to the calculation is lower than the calculation according to the theory of the cost of processing method as shown in the following table:

Table 3 Differences in basic prices of brick press production according to company calculations with theory calculations on CV Batako Angerah Baubau 2014

\begin{tabular}{|clrc|}
\hline \multirow{2}{*}{ No } & The elements & \multicolumn{1}{c|}{$\begin{array}{c}\text { Company } \\
\text { Calculations }\end{array}$} & $\begin{array}{c}\text { Calculation of Cost } \\
\text { of Process Method }\end{array}$ \\
\cline { 3 - 4 } & & Total (IDR) & Total (IDR ) \\
\hline 1 & Raw Material Costs & $141,540,000$ & $145,040,000$ \\
2 & Kindergarten Direct Costs & $24,750,000$ & $24,900,000$ \\
3 & Factory Overhead Costs & $3,500,000$ & $3,535,000$ \\
& Amount & $169,790,000$ & $173,475,000$ \\
\hline
\end{tabular}

Based on the table above, it turns out that the difference in the cost of goods manufactured according to the company's calculations is lower both the cost of production and the total per unit. This difference is caused by the fact that in the calculation of the company the cost of raw material has not been taken into account in the raw material element, the intensive cost in TK directly has not been calculated and the depreciation costs of production assets and equipment have not yet been calculated.

\section{CONCLUSION}

The conclusion of this research is the calculation of cost of production is carried out according to the calculation is 
[4] R Abdullah, D Mahmuda, E Malik, ET Pratiwi, M Rais, A Dja'wa Dan LOD Abdullah (2019) The Influence of Environmental Performance, Environmental Costs, and Firm Size on Financial Performance with CoIDR orate Social Responsibility as Intervening Variables (Empirical Study on Manufacturing Companies Listed on the Indonesia Stock Exchange 2014-2018)

[5] Hartanto, 1977. Akuntansi Untuk Usahawan / Manajemen Accounting. Cetakan kedua Edisi ketiga, Lembaga Penerbit Fakultas Ekonomi, Universitas Indonesia.

[6] James A. Chasindan Ralph S. Polimeni, 1996.Cost Accounting. Penerjemah Drs. Ak Kusnadi dkk. Jilid I. Jakarta :Erlangga

This paper would not have been possible without the support of the Academic Community of Muhammdiyah University of Buton, especially special thanks to Mrs. Ernawati Malik, S.E., M.Ak., Dean of Faculty of Economic, and Dr. Indah Dewi Kusuma, S.H., M.H, Dean of Faculty of Law. We are also grateful to all of those with whom we have had the pleasure to work during this and other related projects. Each of the Director of CV. Batako Anugerah Baubau has provided us extensive personal and professional guidance.

\section{REFERENCES}

[1] Bustami dan Nurlela. 2009. Akuntansi Manufaktur. BFE. Jakarta

[2] Abas Kartadinata, 1998 . Akuntansi dan Analisa Biaya; Suatu Pendekatan Terhadap Tingkah Laku Biaya. Cetakan kedua, Jakarta ; Bina Aksara

[3] Adolph Matz and Milton F. Usry, 1996. Cost Accounting; Perencanaan Biaya dan Pengendalian. Terjemahan oleh Alfonsus Sirait dan Herman Wibowo, Jakarta; Erlangga
[7] Abdullah, R., Malik, E., Pratiwi, E. T., Abdullah, L. O. D., \& Sulili, A. (2019, February). Influence of coIDR orate social responsibility on company performance. In IOP Conference Series: Earth and Environmental Science (Vol. 235, No. 1, p. 012004). IOP Publishing.

[8] Manulang, 1977, Pengantar Ekonomi Perusahaan, Penerbit Ghalia Indonesia, Jakarta.

[9] Nur Indriantoro, 2002, Metodologi Penelitian Bisnis, Cetakan Kedua, Yogyakara;Penerbit BFEE UGM.

[10] Mas'ud Machfoed, 1996. Metode penelitian Empiris, edisi lima, Cetakan pertama, Yogyakarta ; STIE Wiya Wiala

[11] Usry dan Hammer. 2004. Cost Accounting. Salemba Empat.

[12] Mulyadi, 1990. Akuntansi Biaya; Penentuan Harga Pokok dan Pengendalian Biaya. Edisi keempat. Yogyakarta ; BPFE UGM. 